\title{
Management of soft-tissue sarcomas; treatment strategies, staging, and outcomes
}

\author{
Eyal M. Ramu ${ }^{1,2,3}$, Matthew T. Houdek ${ }^{1,2,3, *}$, Christian E. Isaac ${ }^{1,2,3}$, Colleen I. Dickie ${ }^{4}$, \\ Peter C. Ferguson ${ }^{1,2,3}$, and Jay S. Wunder ${ }^{1,2,3}$ \\ ${ }^{1}$ University of Toronto Musculoskeletal Oncology Unit, Mount Sinai Hospital, Toronto, M5G 1X5 Ontario, Canada \\ 2 Department of Surgical Oncology, Princess Margaret Cancer Center, University of Toronto, Toronto, M5G 2C4 Ontario, Canada \\ 3 Division of Orthopedic Surgery, Department of Surgery, University of Toronto, Toronto, M5G 2C4 Ontario, Canada \\ 4 Department of Radiation Oncology, Princess Margaret Cancer Center, University of Toronto, Toronto, M5G 2C4 Ontario, Canada
}

Received 1 November 2016, Accepted 3 January 2017, Published online 10 March 2017

\begin{abstract}
Soft-tissue sarcomas (STS) are a rare group of malignant tumors which can affect any age group. For the majority of patients who present with a localized STS, treatment involves a multidisciplinary team decision-making approach ultimately relying on surgical resection with or without adjuvant radiation for successful limb salvage. The goals of treatment are to provide the patient with a functional extremity without local tumor relapse. The purpose of this article is to review the treatment of extremity STS, with a focus on staging, treatment options, and outcomes.
\end{abstract}

Key words: Soft tissue sarcoma, Outcome, Management, Reconstruction.

\section{Introduction}

Soft-tissue sarcomas (STS) are a diverse group of rare malignant tumors which arise from mesenchymal tissue. Approximately 11,000 new cases of STS are diagnosed each year in the United States, accounting for $<1 \%$ of all cancers [1]. STS can occur over all age ranges, however the median age at diagnosis is 56-65 years, peaking in the 8th decade [2]. STS can arise anywhere in the body; however, the extremities account for $60 \%$ of cases, with the thigh being the most common site of disease [2]. STS are classified based on the mature tissue they resemble, with nearly 100 histologic subtypes in the World Health Organization (WHO) classification [3]. These subtypes vary based on molecular characteristics, clinical behavior, and response to treatment. Low-grade tumors may be locally invasive but rarely metastasize. Higher grade tumors exhibit more aggressive behavior with a more substantial risk of mortality due to the development of metastatic disease (predominantly to the lungs) [4].

\section{Etiology, clinical presentation, and diagnosis}

The etiology of most STS remains unknown; however, there are certain environmental factors and genetic predispositions which have been associated with the development of some types of STS, including neurofibromatosis and

\footnotetext{
*Corresponding author: houdek.matthew@mayo.edu
}

Li-Fraumeni syndrome. The initial signs and symptoms of a STS may vary depending on the tumor site, subtype, and grade. Most commonly patients present with an enlarging painless mass, however tumor growth can cause pain via a mass effect on nearby neurovascular structures.

Certain tumors have a tendency to appear at a certain age (e.g. liposarcoma in adults and rhabdomyosarcoma in children). Likewise, certain STS are more common in specific anatomic locations: liposarcoma is more common in the lower extremity, whereas synovial sarcoma, epithelioid sarcoma, and fibrosarcoma are encountered more often in the upper extremity [4]. Rapid growth raises concern for a malignant diagnosis, while fluctuations in size can be seen in benign lesions such as ganglion cysts and vascular malformations. A small, soft, superficial, mobile mass is most likely to be benign [5]. Asking the patient to contract the muscle adjacent to the mass and assessing its subsequent mobility can help in defining the relationship of the mass to the underlying fascia. Rarely $(<5 \%)$ STS metastasize to lymph nodes, but some histologic subtypes (synovial sarcoma, rhabdomyosarcoma, epithelioid sarcoma, clear cell sarcoma, and angiosarcoma) have a higher propensity for lymphatic spread and in those cases regional lymph nodes should be assessed $[6,7]$.

\section{Diagnosis of a soft-tissue sarcoma}

There are three factors which need to be evaluated as part of the investigation of a patient with a STS: (1) local extension, 
(A)

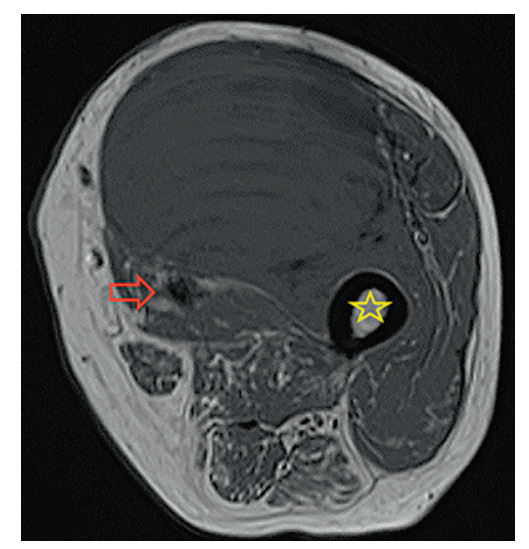

(C)



(B)

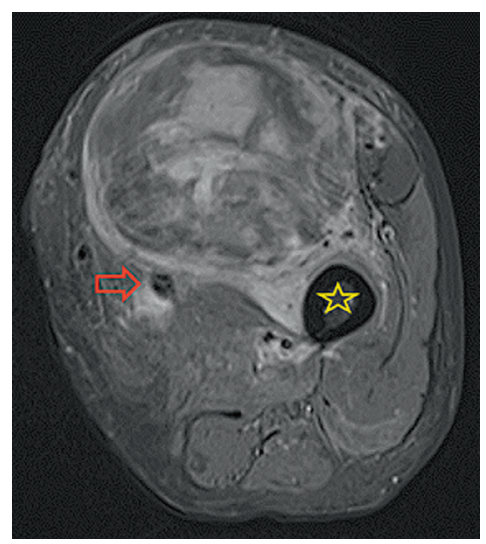

(D)



Figure 1. Selected T1 (A) and fat-saturated T2 (B) axial as well as fat-saturated coronal T2 (C) MRI images of a 60-year-old patient with a large, deep mass located in the anterior thigh. On the pretreatment imaging the mass was intimately associated with the femoral neurovascular bundle (arrow) as well as the periosteum of the femur (star). A biopsy was performed and showed high-grade pleomorphic rhabdomyosarcoma. The mass measured approximately $27 \mathrm{~cm}$ cranial/caudal however was associated with peritumoral edema which spanned nearly the entire length of the femur on coronal fat-saturated T2 (D) MRI images.

(2) histological diagnosis, and (3) staging of metastases. Each of these pieces of information plays an important role in developing a patient-specific treatment plan $[8,9]$.

\section{Assessment of local extension}

STS generally spread along tissue planes, compressing the surrounding tissues and typically do not violate anatomic barriers such as fascia or bone. It is unusual for a STS to invade bone, but when it occurs, bone invasion is associated with a significant reduction in overall survival [10]. Likewise the microscopic extent of tumor cells in the edema surrounding a STS, as seen on magnetic resonance imaging (MRI), could represent a cause of local recurrence if left untreated [11].
Imaging evaluation is best performed by MRI of the extremity. Plain radiographs are rarely required but can help identify bone remodeling, bone invasion, and soft-tissue calcification or ossification [12]. MRI is considered the "gold standard" for defining the local extent of the tumor and surrounding edema (Figure 1) [11]. MRI technology can reconstruct a three-dimensional model from cross-sectional images and provides pertinent anatomic information related to the tumor and its proximity to critical neurovascular structures and bone. This information is important for planning surgical excision, as the strongest predictor of local recurrence is a positive surgical margin $[13,14]$. The addition of gadolinium contrast to the MRI can help differentiate between cystic areas representing hemorrhage or necrosis based on peripheral 
rim enhancement, and solid viable areas of tumor based on enhancement throughout the lesion. An MRI demonstrating a heterogeneous mass with predominantly low signal intensity on T1-weighted images, high signal intensity on T2-weighted images, and post-gadolinium contrast enhancement is very characteristic of a STS (Figure 1) [15]. Likewise magnetic resonance angiography is also a very useful modality in assessing the relationship of STS to adjacent neuromuscular bundle.

\section{Histological diagnosis}

Pathological assessment is necessary to define the histologic subtype and grade and should be obtained prior to definitive treatment if there is concern for a STS. Different subtypes can vary in their clinical behavior and response to treatment and histologic grade has been identified as one of the strongest predictors of metastatic risk and disease-free survival [14, 16-19].

In the case of a suspected STS, biopsy should be performed prior to excision in order to avoid inadequate surgery. Two types of biopsies are commonly used today: needle (fineneedle aspiration (FNA), core needle biopsy (CNB)) and open biopsy (incisional, excisional). Needle biopsies are less time consuming, relatively inexpensive, cause minimal morbidity, limited soft-tissue contamination, and can be performed in an outpatient clinic setting [20-23]. FNA may be able to establish the presence of malignancy, but CNB is usually required as it provides the pathologist with an adequate tissue sample, and it has been suggested that 4-6 cores of tumor tissue are necessary for an accurate diagnosis [20-24].

Incisional biopsy provides a larger amount of tissue for histologic assessment and grading and thereby provides a better estimate of prognosis [24]. An operative biopsy should be carefully planned using a longitudinal/extensile incision that can be excised as part of a definitive surgical incision should the final diagnosis confirm a STS. Careful hemostasis is critical to minimize the risk of soft-tissue contamination by hematoma. Excisional biopsy of an extremity mass without a definitive diagnosis is usually reserved for small, superficial, and mobile masses which are most likely to be benign, or situations in which the diagnosis is in doubt but excision can be easily performed with a true wide margin.

\section{Staging}

The diagnostic workup is completed by staging investigations for regional and distant metastases. The two most commonly used staging systems are the American Joint Committee on Cancer (AJCC) staging system and the Musculoskeletal Tumor Society (MSTS) staging system [25]. Both of these staging systems utilize the local extent of the tumor (size and depth for AJCC vs. compartment status for MSTS), histologic grade, and the presence or absence of metastases.

Extremity STS most commonly metastasize hematogenously with a strong predilection for the lungs and $10 \%$ of patients will have detectable pulmonary disease at the time of initial presentation [26]. The initial workup should include systemic staging by chest computed tomography (CT)-scan to evaluate the lungs. A bone scan can be used to evaluate for the rare occurrence of metastatic bone disease although it can be negative even in the presence of osseous metastases. In addition to a bone scan, a positron emission tomography (PET) scan can be helpful in staging of recurrent disease. If the biopsy confirms the diagnosis of a subtype of STS prone to metastasize to lymph nodes, imaging of the regional lymph nodes with a CT scan should be undertaken.

\section{Treatment of extremity soft-tissue sarcomas}

Every patient with a soft-tissue sarcoma in the upper or lower extremity will require an individualized treatment plan. Various patient, tumor, and anatomic characteristics need to be evaluated in a multidisciplinary setting in order to generate the optimal treatment plan.

Most localized extremity STS are best treated surgically with or without radiation therapy. Chemotherapy is usually reserved for management of patients with metastatic disease either at presentation or following resection of the primary tumor, or less commonly for attempting to facilitate local tumor down-staging for very extensive lesions which might not otherwise be amenable to limb sparing surgery. Isolated lymph node metastases are somewhat of an exception however as long-term survival is still possible following surgical resection [7]. The overall treatment goal is to achieve maximal oncologic control and render the least functional impairment. As is the case in all areas of medicine, a thoughtful "risksbenefits" discussion is critical and each patient should be involved in the multidisciplinary decision-making process.

The term "oncologic control" refers to minimizing each patient's risk of local and systemic recurrence with current treatment modalities. Historically, many soft-tissue sarcomas of the extremity were treated with amputation or radical resection alone. Although this approach provided a high degree of local tumor control, it was at the expense of residual limb function and yet still left patients at risk for developing metastatic disease. The introduction of adjuvant radiotherapy and developments in cross-sectional imaging, particularly MRI, has allowed more conservative resection margins to be considered safe, thereby extending the indications for limb salvage. In general, modern limb-salvage techniques can achieve comparable oncologic control with superior functional outcomes compared to amputation. As a result, primary amputation for management of extremity STS is rarely indicated except for situations with very extensive and locally invasive disease (Table 1) [27].

Radiation therapy is recommended for all STS where surgery will provide less than a wide negative resection margin. Adjuvant radiation can be given preoperatively or postoperatively and this was the subject of a randomized clinical trial (RCT) [28]. Preoperative radiation typically prescribes a total of 50 Gy delivered in 2 Gy daily fractions over five weeks followed by surgery four to six weeks after the completion of radiation. In comparison, postoperative radiation begins approximately four to six weeks after surgery or once the wound has adequately healed, and typically involves 
Table 1. Indication for primary amputation for extremity soft tissue sarcomas.

Indications for amputation [27]

1) Limb salvage would result in inadequate function of the limb.

2) Composite tissue involvement.

3) Prior unplanned excision (resulting in widespread tissue contamination) with exposed multiple neurovascular structures and/or bone.

4) Elderly patients with major medical comorbidities who are unlikely to tolerate a major operation

(a potential indication for primary amputation).

30-33 daily fractions delivered over six weeks to a total of 60-66 Gy. Preoperatively the radiation field encompasses the tumor and an additional surrounding region to account for tissues that may have microscopic disease. Postoperatively a larger dose of radiation is given to a larger target volume because of the theoretical issues of tissue hypoxia, and the fact that the entire surgical wound needs to be included in the treatment field. Preoperative radiation is associated with a significantly higher wound complication rate, [28] which can be partially minimized by the timing of surgery [29, 30]. Wound complications following preoperative radiation can complicate patients' short-term outcome but are usually resolvable and have little impact on long-term function [31, 32]. In comparison, patients treated with postoperative radiation are more likely to develop significant fibrosis, lymphedema, joint stiffness, and pain which correlate with significantly worse longterm functional outcome [31, 32]. Long-term follow-up of patients in this randomized trial demonstrated the sequelae following postoperative radiation can be permanently disabling [31]. Importantly, there were no differences in local or systemic disease recurrence between patients treated with preoperative or postoperative radiation.

In the above RCT, patients who received 50 Gy preoperatively and had positive resection margins were treated with an additional 16 Gy radiation boost following surgery. Two subsequent studies showed that this postoperative radiation boost increased the total dose of radiation without offering any detectable advantage in local control so this practice has since been abandoned at our institution, as well as many others in North America, but has yet to become a widely accepted treatment policy $[33,34]$. In cases with particularly radiosensitive tumors, such as myxoid liposarcoma, preoperative radiation can lead to substantial tumor shrinkage prior to surgery and is associated with excellent outcomes [35-37]. Although preoperative radiation is associated with an increased risk of early wound complications, it does not impede successful microvascular anastomosis in cases needing free flaps for soft-tissue reconstruction, but avoids direct radiation to a free tissue transfer, rotational flap, or skin graft when needed for wound coverage [38].

Image-guided intensity-modulated radiation therapy (IMRT) is becoming the standard of care for sarcoma patients at our institution and can be provided in either the preoperative or postoperative setting (Figure 2). The potential advantage of IMRT is its ability to "sculpt" the treatment volume and thereby provide less radiation to surrounding normal tissues,
(A)

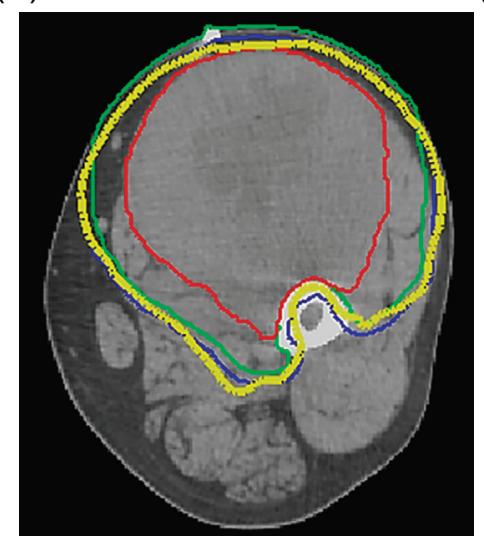

(B)

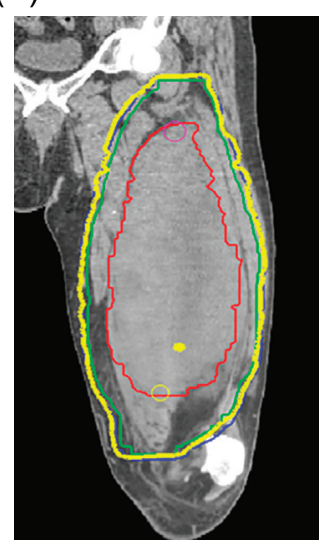

Figure 2. Preoperative radiotherapy planning volumes for the patient in Figure 1 are shown on axial (A) and coronal (B) CT images. The Gross Tumor Volume (GTV) is demonstrated by the solid red contour; Clinical Target Volume (CTV) is demonstrated by the green solid contour; Planning Target Volume (PTV) is shown by the blue solid contour; and the thick yellow line represents the prescribed radiotherapy dose volume. Note that intensity-modulated radiotherapy (IMRT) was used to adequately encompass the radiotherapy target volume while avoiding the bone by sculpting the high dose volume around the femoral cortex for protection purposes (A), while also accounting for the peritumoral edema surrounding the lesion (B) which was demonstrated on the coronal fat-saturated T2 post-gadolinium image in Figures 1C and 1D.

such as skin, bone, and neurovascular structures, without compromising target coverage [39]. In a Phase II clinical trial for patients with lower extremity STS, preoperative IMRT substantially decreased the radiation dose to planned overlying skin flaps as well as bone, decreased the wound complication rate and need for surgical intervention for wound complications, and led to a higher rate of primary wound closure and less need for soft-tissue flaps [29, 30, 39]. In addition, there were no bone fractures, a low risk of local recurrence ( $88 \%$ five-year local recurrence-free survival), low rates of radiation toxicities, and favorable functional outcomes.

Surgical margin has an important impact on outcome because it may be the only independent risk factor under the surgeon's control in the treatment of an extremity STS $[14,40,41]$. Other well-known risk factors such as tumor size, grade, depth, and patient age are considered non-modifiable at disease presentation [14]. The definition of a "safe" surgical margin continues to evolve during the limb-salvage era. There are certain context-specific differences in terms of local oncologic control based on margin status [40, 41]. For superficial STS, or small and deep STS, surgery alone can provide a high degree of local control as long as true wide negative resection margins (i.e. $1-2 \mathrm{~cm}$ of surrounding normal tissue or a fascial barrier) can be obtained. Gerrand et al. classified positive margins into low and high-risk groups based on the risk of local recurrence [41]. They found that microscopic positive margins that occurred following planned dissections close to major blood vessels, motor nerves, or bone, in order to spare those critical structures, were associated with low 
(A)

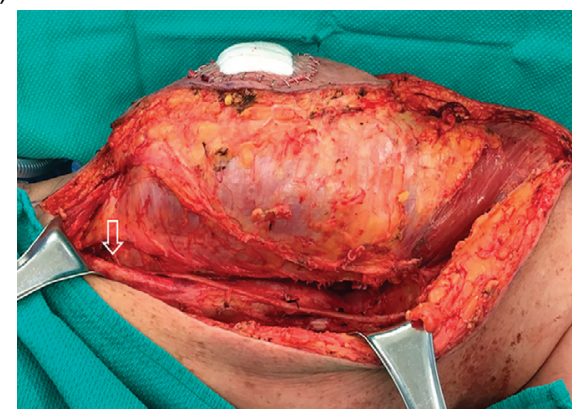

(C)

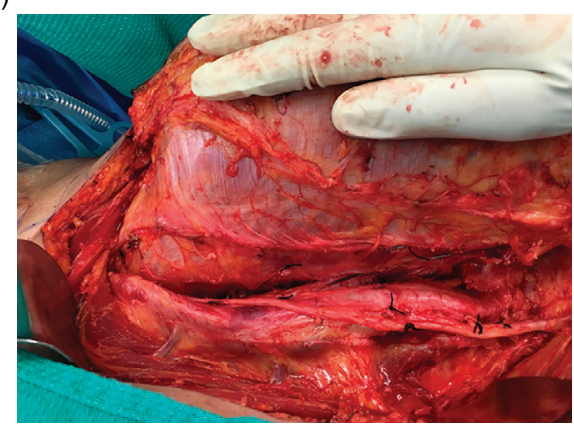

(B)

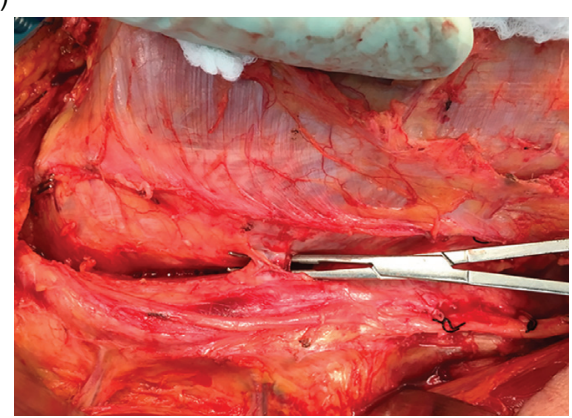

(D)

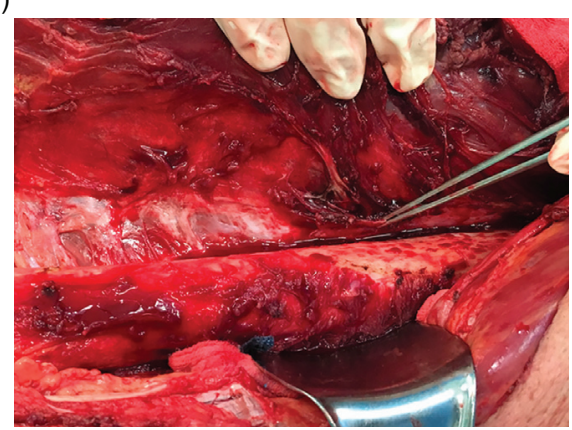

(E)

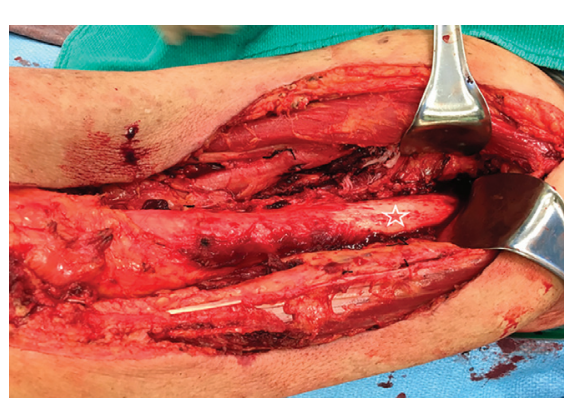

Figure 3. At the time of surgical excision (A), the femoral neurovascular bundle was very close to the tumor (arrow), with multiple perforating blood vessels entering the tumor (B). Due to preoperative IMRT it was safe to create a dissection plane between the tumor and the neurovascular bundle (C). The periosteum was also raised from the femur (pointer) as a margin along the tumor in the region where it was adherent to the bone (D). Although preoperative imaging showed the tumor to be very close to bone along the entire length of the femur, it was actually adherent to bone over a shorter length, so that only a small portion of the periosteum had to be removed (star) from the femoral shaft (E). The final pathological tumor resection margins were negative.

rates of local recurrence when combined with radiation therapy. In contrast, an unplanned positive soft-tissue margin or a positive margin obtained following re-excision to salvage an unplanned excision performed elsewhere with positive margins, were both associated with local recurrence rates greater than $30 \%$. Therefore it is best to avoid positive margins in either of these scenarios, if at all possible, in order to achieve a good outcome. In the case of a previously unplanned excision, although there is no association between the detection of sarcoma at the second procedure and the initial size or grade of the tumor, use of preoperative radiation, or the time lapse between interventions, identification of tumor in the re-excision specimen pathologically does significantly increase the risk for local tumor relapse [42]. At our institution we advise wide re-excision if possible for all patients who present following an initial unplanned excision with positive margins.
Other studies have assessed the safety and efficacy of close dissection along bone or critical neurovascular structures to facilitate limb salvage combined with radiation therapy (Figure 3). Clarkson et al. found no difference in local or systemic recurrence rates when epineural dissection was performed for buttock or thigh STS in order to preserve the sciatic nerve [43]. O'Donnell et al. showed that a positive margin following a close dissection to spare a major neurovascular structure or bone is relatively safe in terms of local recurrence, but is associated with worse cause-specific survival [44]. This study also showed that if a nerve or vessel is surrounded by tumor or a bone is invaded, complete resection of that structure en-bloc with the tumor to facilitate negative margins did not improve systemic disease control. Therefore the biology of each tumor plays a critical role in determining the ultimate oncologic outcome for the patient. These results suggest that critical structures can be preserved, in the context 
Table 2. Risk factors for radiation-associated pathological femur fracture.

Risk factors [48, 50]

1) Increasing age at index procedure.

2) Large tumor size.

3) Location of tumor (anterior thigh compartment is at greatest risk).

4) Degree of periosteal stripping.

5) Female gender.

6) Postoperative radiation.

7) High dose radiation to bone based on bone avoidance principles.

of multidisciplinary treatment, unless they are invaded or completely encased by tumor [43-46]. In cases where tumor invades into bone it may be necessary to resect a segment of bone and reconstruct the osseous defect in order to obtain an adequate surgical margin and facilitate limb salvage [10]. Otherwise a periosteal margin provides adequate local control when combined with adjuvant radiation (Figure 3).

Fractures in the radiation field can be particularly problematic because radiated bone does not reliably heal. Radiation-related fractures most commonly affect the femur and are significantly more frequent following postoperative radiation, likely due to the combination of higher radiation dose and larger treatment field [47-49]. High-risk patients can be identified using patient and treatment variables which have been combined into a nomogram (Table 2) [50], as well as specific bone radiation-avoidance principles [48]. Patients who are identified as high risk for developing a pathological fracture should have close follow-up and may benefit from prophylactic internal fixation, either at the time of the procedure or in a staged fashion [50].

\section{Soft-tissue reconstruction}

The primary goal of oncologic surgery is to achieve negative surgical margins, and this often means that large soft-tissue defects are left following resection which are not amenable to primary wound closure [51]. Soft-tissue reconstruction following resection of a STS follows the theory of orthoplastic reconstruction based on the "reconstructive ladder" as described by Levin [52]. According to this protocol, the reconstructive surgeon uses the simplest procedure to cover a wound (e.g. primary closure) and then proceeds to more complex procedures to achieve wound closure and maximum functional benefit.

\section{Skin grafting}

Following primary wound closure; skin grafting is the first rung of the reconstructive ladder. Split thickness skin grafting (STSG) can be used in a well-vascularized wound to cover muscle and tendons with paratenon. A historic contraindication to STSG was a radiated wound bed; however, recent studies have shown that a STSG can provide durable coverage of a radiated wound, and healing may be enhanced with a negative pressure wound dressing [53].

\section{Flaps}

If the soft-tissue defect following STS resection precludes primary wound closure, and/or there are exposed nerves, vessels, bone, tendon without paratenon or hardware, the wound will need flap coverage as opposed to skin grafting. Flaps can be either local pedicled flaps or free flaps depending on the anatomic location and size of the defect requiring coverage (Table 3). Rotational flaps are highly predictable but recent advances have reduced the failure rate of free flaps to $1-4 \%$ [54]. Historically it was thought the vascular anastomosis for a free flap needed to be outside the zone of radiation; however, a recent study by Townley et al. showed that preoperative radiation does not increase the rate of microvascular complications [38].

\section{Functional outcome}

Following limb-salvage surgery or amputation, patients may be left with significant physical and emotional disability and reduced overall quality of life (QOL). In order to evaluate the impact of these procedures on patients, various functional assessments have been utilized. The most commonly used outcome measures are the Toronto Extremity Salvage Score (TESS) and the Musculoskeletal Tumor Society (MSTS) scoring system [55-57]. The TESS is a patient reported questionnaire which is validated to assess activity limitations, while the MSTS-87 is a physician rating based on function at specific anatomic locations (e.g. hip, knee) while the MSTS-93 is a physician rating based on function of the entire extremity (upper vs. lower) [55-57].

Resection of extremity STS is frequently a very invasive procedure, which can significantly impact a patient's life; however, a majority of patients are left with moderate-to-high function following limb salvage [32, 58] (Table 4). Predictors of worse functional outcome following resection of STS include large tumor size, high-grade tumors, deep tumors, resection of bone, and sacrifice of a major motor nerve [58, 59]. In addition, patients' inability to partake in life roles following treatment, [60] and their preoperative expectations [61] can have a significant impact on eventual QOL. Surprisingly additional factors, which may impart worse disease-specific survival and increase the risk of postoperative complications, may not impact the functional outcome. These factors include a radiation-induced sarcoma, [62] need for vascular reconstruction, [46] anatomic location, [59, 63, 64] and use of a free or pedicled flap $[63,65]$.

\section{Surveillance}

The majority of local recurrences as well as lung metastases will become evident within the first two years following treatment. As a result, high-risk patients are seen in follow-up every three months for the first two years for clinical examination and a chest x-ray or CT-scan. We only perform MRI of the surgical site or lymph nodes as part of regular follow-up if there is clinical concern for local or regional recurrence, based 
Table 3. Common flaps for extremity reconstruction.

\begin{tabular}{|c|c|c|c|}
\hline Type of flap & Free vs. Pedicled & Pedicle & Indication \\
\hline \multicolumn{4}{|l|}{ Fasciocutaneous flaps } \\
\hline Radial Forearm & Free or Pedicled & $\begin{array}{l}\text { Radial artery antegrade } \\
\text { or retrograde }\end{array}$ & $\begin{array}{l}\text { Smaller soft tissue defects, exposed tendons, } \\
\text { bone, joints, or neurovascular structures }\end{array}$ \\
\hline Anterolateral thigh (ALT) & Free or Pedicled & $\begin{array}{l}\text { Descending branch lateral } \\
\text { femoral circumflex }\end{array}$ & $\begin{array}{l}\text { Large soft-tissue defects, coverage of exposed } \\
\text { tendons, bone, joints, and neurovascular } \\
\text { structures }\end{array}$ \\
\hline \multicolumn{4}{|l|}{ Muscle flaps } \\
\hline Latissimus dorsi & Free or Pedicled & Thoracodorsal & $\begin{array}{l}\text { Large soft-tissue defects with exposed bone, } \\
\text { hardware, and neurovascular structures. } \\
\text { Functional restoration of the elbow }\end{array}$ \\
\hline $\begin{array}{l}\text { Rectus abdominis } \\
\text { (TRAM or VRAM)* }\end{array}$ & Free or Pedicled & Deep inferior epigastric & $\begin{array}{l}\text { Large soft-tissue defects with exposed bone, } \\
\text { hardware, and neurovascular structures }\end{array}$ \\
\hline Gracilis & Free & $\begin{array}{l}\text { Medial femoral circumflex } \\
\text { artery }\end{array}$ & $\begin{array}{l}\text { Medium soft-tissue defects with exposed bone, } \\
\text { hardware, and neurovascular structures. Can } \\
\text { also be innervated as a functional } \\
\text { reconstruction }\end{array}$ \\
\hline Gastrocnemius & Pedicled & Medial or lateral sural artery & $\begin{array}{l}\text { Medium soft-tissue defects around the proximal } \\
\text { tibia and knee. Functional restoration of the } \\
\text { extensor mechanism of the knee }\end{array}$ \\
\hline
\end{tabular}

* TRAM $=$ transverse rectus abdominis myocutaneous flap and VRAM = vertical rectus abdominis myocutaneous flap.

Table 4. Functional outcome following sarcoma resection.

\begin{tabular}{|c|c|c|c|c|}
\hline Paper & $\begin{array}{c}\text { Patient } \\
\text { population }\end{array}$ & Comparison & $\begin{array}{l}\text { Outcome } \\
\text { measure }\end{array}$ & Impact on functional outcome \\
\hline Davis et al. [58] & $\begin{array}{l}\text { Lower extremity } \\
\text { STS }\end{array}$ & $\begin{array}{r}\text { Function of patients } \\
\text { with limb salvage }\end{array}$ & $\begin{array}{l}\text { - MSTS } 87 \\
\text { - MSTS } 93 \\
\text { - TESS } \\
\text { - SF-36 }\end{array}$ & $\begin{array}{l}\text { Large tumor size: } \\
\text { - Lower extremity MSTS 1987, MSTS 1993, TESS } \\
\text { Motor nerve resection (femoral, obturator, sciatic, peroneal, } \\
\text { and posterior tibial nerves): } \\
\text { - Lower MSTS 1987, MSTS 1993, TESS } \\
\text { Postoperative complications: } \\
\text { - Lower MSTS } 1987 \\
\text { High-grade tumors: } \\
\text { - Lower MSTS } 1993 \text { and TESS } \\
\text { Bone resection: } \\
\text { - Lower MSTS } 1993\end{array}$ \\
\hline Davis et al. [32] & Extremity STS & $\begin{array}{l}\text { Pre- vs. Postoperative } \\
\text { radiotherapy }\end{array}$ & $\begin{array}{l}\text { - MSTS } \\
\text { - TESS } \\
\text { - SF-36 }\end{array}$ & $\begin{array}{l}\text { Postoperative radiotherapy: } \\
\text { - Improved MSTS, TESS, and SF-36 at } 6 \text { weeks postop- } \\
\text { erative only } \\
\text { SF-36 compared to normative data: } \\
\text { - Lower for both treatment arms across all time points } \\
\text { Wound complications: } \\
\text { - Lower MSTS at } 6 \text { weeks, } 3,6,12 \text {, and } 24 \text { months } \\
\text { - Increased disability compared to baseline TESS } \\
\text { Large tumor size ( }>10 \mathrm{~cm} \text { ): } \\
\text { - Lower MSTS scores at } 6,12 \text {, and } 24 \text { months } \\
\text { Motor nerve resection: } \\
\text { - Lower MSTS scores } \\
\text { Previous unplanned excision: } \\
\text { - Lower TESS score at } 3,6,12 \text {, and } 24 \text { months }\end{array}$ \\
\hline
\end{tabular}


Table 4. (continued)

\begin{tabular}{|c|c|c|c|c|}
\hline Paper & $\begin{array}{c}\text { Patient } \\
\text { population }\end{array}$ & Comparison & $\begin{array}{c}\text { Outcome } \\
\text { measure }\end{array}$ & Impact on functional outcome \\
\hline Davis et al. [31] & Extremity STS & $\begin{array}{l}\text { Late morbidity: } \\
\text { - Pre- (50 Gy) vs. } \\
\text { Postoperative } \\
\text { (66 Gy) } \\
\text { radiotherapy }\end{array}$ & $\begin{array}{l}\text { - MSTS } \\
\text { - TESS }\end{array}$ & $\begin{array}{l}\text { Subcutaneous fibrosis: } \\
\text { - Decreased MSTS and TESS } \\
\text { Joint stiffness: } \\
\text { - Decreased MSTS and TESS } \\
\text { Extremity lymphedema: } \\
\text { - Decreased MSTS and TESS } \\
\text { Pre- vs. Postoperative radiotherapy: } \\
\text { - No difference in MSTS or TESS } \\
\text { - Trend toward greater fibrosis with postoperative } \\
\text { radiotherapy }\end{array}$ \\
\hline Payne et al. [63] & $\begin{array}{l}\text { Upper extremity } \\
\text { STS with flap } \\
\text { coverage }\end{array}$ & $\begin{array}{l}\text { Pedicled vs. Free flap } \\
\text { for wound coverage }\end{array}$ & $\begin{array}{l}\text { - MSTS } 87 \\
\text { - MSTS } 93 \\
\text { - TESS }\end{array}$ & $\begin{array}{l}\text { Pedicled vs. free flaps: } \\
\text { - Decreased MSTS } 87 \text { from pre- to postoperative in } \\
\text { patients with either pedicled or free flap } \\
\text { - Decreased MSTS } 93 \text { for free flaps } \\
\text { - No difference in TESS between groups } \\
\text { - Patients rated their function better compared to the } \\
\text { actual rated impairment }\end{array}$ \\
\hline Davis et al. [66] & $\begin{array}{l}\text { Lower extremity } \\
\text { limb salvage } \\
\text { sarcoma patients }\end{array}$ & $\begin{array}{l}\text { Relationship of } \\
\text { symptoms } \\
\text { to function during } \\
1 \text { st year } \\
\text { postoperative }\end{array}$ & $\begin{array}{l}\text { - Stiffness } \\
\text { - Fatigue } \\
\text { - Pain } \\
\text { - Weakness } \\
\text { - Limited } \\
\text { range of } \\
\text { motion } \\
\text { - TESS }\end{array}$ & $\begin{array}{l}\text { Stiffness: } \\
\text { - Plateaus at } 3 \text { months } \\
\text { - Remains constant over the year } \\
\text { Fatigue: } \\
\text { - Plateaus at } 3 \text { months } \\
\text { - Remains constant over the year } \\
\text { Pain: } \\
\text { - Constant for } 3 \text { months then declines over study } \\
\text { Weakness: } \\
\text { - Constant for } 3 \text { months then declines over study } \\
\text { Limited Range of Motion: } \\
\text { - Constant decline over study } \\
\text { TESS: } \\
\text { - Presence of pain, stiffness, weakness, and limited range } \\
\text { of motion were predictors of worse outcome }\end{array}$ \\
\hline Gerrand et al. [59] & $\begin{array}{l}\text { Lower Extremity } \\
\text { Limb Salvage } \\
\text { Sarcoma patients }\end{array}$ & $\begin{array}{l}\text { Sarcoma location and } \\
\text { functional outcome: } \\
\text { - Groin/Femoral } \\
\text { triangle } \\
\text { - Buttock } \\
\text { - Anterior thigh } \\
\text { - Medial thigh } \\
\text { - Posterior thigh } \\
\text { - Popliteal fossa } \\
\text { - Posterior calf } \\
\text { - Anterolateral leg } \\
\text { - Foot and ankle }\end{array}$ & $\begin{array}{l}\text { - MSTS } 93 \\
\text { - TESS }\end{array}$ & $\begin{array}{l}\text { Deep vs. superficial: } \\
\text { - Superficial tumors have improved MSTS and TESS } \\
\text { scores } \\
\text { Superficial tumors: } \\
\text { - No decrease in MSTS or TESS from to pre- to } \\
\text { postoperative } \\
\text { Deep Tumors: } \\
\text { - No difference in MSTS or TESS based on tumor } \\
\text { location } \\
\text { Groin/Femoral triangle tumors: } \\
\text { - Increased pain based on the MSTS compared to other } \\
\text { anatomic areas } \\
\text { - Decreased ability to sit, put on socks, getting in and out } \\
\text { of bath, bending to pick up items } \\
\text { - More likely to have a limp or gait handicap } \\
\text { Buttock/Posterior thigh: } \\
\text { - Decreased ability to sit }\end{array}$ \\
\hline
\end{tabular}


Table 4. (continued)

\begin{tabular}{|c|c|c|c|c|}
\hline Paper & $\begin{array}{c}\text { Patient } \\
\text { population }\end{array}$ & Comparison & $\begin{array}{l}\text { Outcome } \\
\text { measure }\end{array}$ & Impact on functional outcome \\
\hline Ghert et al. [46] & $\begin{array}{l}\text { Lower extremity } \\
\text { limb salvage } \\
\text { sarcoma patients }\end{array}$ & $\begin{array}{l}\text { Vascular } \\
\text { reconstruction and } \\
\text { functional outcome: } \\
\text { - Femoral } \\
\text { - Iliofemoral } \\
\text { - Popliteal } \\
\text { - Tibial/Peroneal }\end{array}$ & - TESS & $\begin{array}{l}\text { Vascular reconstruction: } \\
\text { - More likely to need a muscle flap, have a wound com- } \\
\text { plication, sustain a deep vein thrombosis (DVT), suffer } \\
\text { from edema of the limb, and require an amputation } \\
\text { - No difference in the postoperative TESS }\end{array}$ \\
\hline \multirow[t]{3}{*}{ Jones et al. [45] } & \multirow[t]{3}{*}{$\begin{array}{l}\text { Lower extremity } \\
\text { limb salvage } \\
\text { sarcoma patients }\end{array}$} & $\begin{array}{l}\text { Nerve resection and } \\
\text { functional outcome: } \\
\text { - Femoral } \\
\text { - Sciatic }\end{array}$ & \multirow[t]{3}{*}{$\begin{array}{l}\text { - MSTS } 87 \\
\text { - MSTS } 93 \\
\text { - TESS }\end{array}$} & \multirow{3}{*}{$\begin{array}{l}\text { Femoral nerve resection: } \\
\text { - No difference in MSTS 87, MSTS 93, or TESS } \\
\text { between patients with sciatic nerve resection, gender- } \\
\text { matched large anterior thigh tumors, or all patients } \\
\text { with large anterior thigh tumors } \\
\text { - Long-term risk of falling which could lead to fracture }\end{array}$} \\
\hline & & $\begin{array}{l}\text { Comparison of } \\
\text { femoral nerve resec- } \\
\text { tion and location: }\end{array}$ & & \\
\hline & & $\begin{array}{l}\text { - Gender-matched } \\
\text { large anterior } \\
\text { thigh } \\
\text { - All large anterior } \\
\text { thigh }\end{array}$ & & \\
\hline Pradhan et al. [67] & $\begin{array}{l}\text { Patients with STS } \\
\text { of the adductor } \\
\text { compartment }\end{array}$ & $\begin{array}{l}\text { Outcome of treatment } \\
\text { of adductor } \\
\text { compartment STS }\end{array}$ & - TESS & $\begin{array}{l}\text { Impact on TESS: } \\
\text { - Wound complications and high-grade tumors had lower } \\
\text { TESS } \\
\text { - Timing of radiotherapy (pre- vs. postoperative) had no } \\
\text { effect on TESS } \\
\text { - Need for a muscle flap; had no effect on TESS }\end{array}$ \\
\hline Riad et al. [62] & $\begin{array}{l}\text { Patients with } \\
\text { radiation induced } \\
\text { STS }\end{array}$ & $\begin{array}{l}\text { Outcome of treatment } \\
\text { in patients with a } \\
\text { radiation-induced } \\
\text { STS compared to } \\
\text { patients with a } \\
\text { sporadic STS }\end{array}$ & $\begin{array}{l}\text { - } \text { MSTS } 87 \\
\text { - TESS }\end{array}$ & $\begin{array}{l}\text { Radiation induced vs. Sporadic STS: } \\
\text { - No difference in the MSTS } 87 \text { or TESS }\end{array}$ \\
\hline
\end{tabular}

MSTS 87 = Musculoskeletal Tumor Society Functional Rating System 1987, a measure of impairment; MSTS 93 = Musculoskeletal Tumor Society Functional Rating System 1993, a measure of impairment; TESS = Toronto Extremity Sarcoma Salvage Score, a measure of functional disability; SF-36 = 36-Item Short Form Health Survey, a quality of life measure.

on physical examination in the clinic or changes noted by the patient. After the first two years high-risk patients are reviewed every six months until five years and then annually until 10 years.

\section{Summary}

Extremity STS are aggressive and rare malignant tumors with several factors such as size, depth, grade, and tumor location which influence outcome. Following a tissue diagnosis and staging, the treatment of patients with STS involves a multidisciplinary team approach and most patients are eligible for limb-salvage surgery, usually combined with radiation. Following treatment the majority of patients can expect a painless and functional extremity.

\section{Conflict of interest}

No conflicts of interest are declared by any author on this study.

Acknowledgements. No disclosures of funding were received for this work from NIH, Wellcome Trust, or HHMI.

\section{References}

1. Siegel RL, Miller KD, Jemal A (2015) Cancer statistics, 2015. CA Cancer J Clin 65(1), 5-29.

2. Pollock RE, Karnell LH, Menck HR, Winchester DP (1996) The National Cancer Data Base report on soft tissue sarcoma. Cancer 78(10), 2247-2257. 
3. Fletcher CD (2014) The evolving classification of soft tissue tumours - an update based on the new 2013 WHO classification. Histopathology 64(1), 2-11.

4. Gerrand CH, Bell RS, Wunder JS, Kandel RA, O'Sullivan B, Catton CN, Griffin AM, Davis AM (2003) The influence of anatomic location on outcome in patients with soft tissue sarcoma of the extremity. Cancer 97(2), 485-492.

5. Frassica FJ, Khanna JA, McCarthy EF (2000) The role of MR imaging in soft tissue tumor evaluation: perspective of the orthopedic oncologist and musculoskeletal pathologist. Magn Reson Imaging Clin N Am 8(4), 915-927.

6. Fong Y, Coit DG, Woodruff JM, Brennan MF (1993) Lymph node metastasis from soft tissue sarcoma in adults. Analysis of data from a prospective database of 1772 sarcoma patients. Ann Surg 217(1), 72-77.

7. Riad S, Griffin AM, Liberman B, Blackstein ME, Catton CN, Kandel RA, O'Sullivan B, White LM, Bell RS, Ferguson PC, Wunder JS (2004) Lymph node metastasis in soft tissue sarcoma in an extremity. Clin Orthop Relat Res 426, 129-134.

8. Casali PG, Blay JY, experts ECECPo (2010) Soft tissue sarcomas: ESMO Clinical Practice Guidelines for diagnosis, treatment and follow-up. Ann Oncol 21(Suppl 5), v198-203.

9. Clark MA, Fisher C, Judson I, Thomas JM (2005) Soft-tissue sarcomas in adults. N Engl J Med 353(7), 701-711.

10. Ferguson PC, Griffin AM, O'Sullivan B, Catton CN, Davis AM, Murji A, Bell RS, Wunder JS (2006) Bone invasion in extremity soft-tissue sarcoma: impact on disease outcomes. Cancer 106(12), 2692-2700.

11. White LM, Wunder JS, Bell RS, O'Sullivan B, Catton C, Ferguson P, Blackstein M, Kandel RA (2005) Histologic assessment of peritumoral edema in soft tissue sarcoma. Int J Radiat Oncol Biol Phys 61(5), 1439-1445.

12. Wu JS, Hochman MG (2009) Soft-tissue tumors and tumor like lesions: a systematic imaging approach. Radiology 253(2), 297-316.

13. Trovik CS, Bauer HC, Alvegard TA, Anderson H, Blomqvist C, Berlin O, Gustafson P, Saeter G, Walloe A (2000) Surgical margins, local recurrence and metastasis in soft tissue sarcomas: 559 surgically-treated patients from the Scandinavian Sarcoma Group Register. Eur J Cancer 36(6), 710-716.

14. Biau DJ, Ferguson PC, Turcotte RE, Chung P, Isler MH, Riad S, Griffin AM, Catton CN, O'Sullivan B, Wunder JS (2011) Adverse effect of older age on the recurrence of soft tissue sarcoma of the extremities and trunk. J Clin Oncol 29(30), 4029-4035.

15. Kransdorf MJ, Murphey MD (2000) Radiologic evaluation of soft-tissue masses: a current perspective. Am J Roentgenol 175(3), 575-587.

16. Pisters PW, Leung DH, Woodruff J, Shi W, Brennan MF (1996) Analysis of prognostic factors in 1,041 patients with localized soft tissue sarcomas of the extremities. J Clin Oncol 14(5), 1679-1689.

17. Coindre JM, Terrier P, Guillou L, Le Doussal V, Collin F, Ranchere D, Sastre X, Vilain MO, Bonichon F, N'Guyen Bui B (2001) Predictive value of grade for metastasis development in the main histologic types of adult soft tissue sarcomas: a study of 1240 patients from the French Federation of Cancer Centers Sarcoma Group. Cancer 91(10), 1914-1926.

18. Coindre JM (2006) Grading of soft tissue sarcomas: review and update. Arch Pathol Lab Med 130(10), 1448-1453.
19. Zagars GK, Ballo MT, Pisters PW, Pollock RE, Patel SR, Benjamin RS, Evans HL (2003) Prognostic factors for patients with localized soft-tissue sarcoma treated with conservation surgery and radiation therapy: an analysis of 1225 patients. Cancer 97(10), 2530-2543.

20. Ball AB, Fisher C, Pittam M, Watkins RM, Westbury G (1990) Diagnosis of soft tissue tumours by Tru-Cut biopsy. Br J Surg 77(7), 756-758.

21. Welker JA, Henshaw RM, Jelinek J, Shmookler BM, Malawer MM (2000) The percutaneous needle biopsy is safe and recommended in the diagnosis of musculoskeletal masses. Cancer 89(12), 2677-2686.

22. Verheijen P, Witjes H, van Gorp J, Hennipman A, van Dalen T (2010) Current pathology work-up of extremity soft tissue sarcomas, evaluation of the validity of different techniques. Eur J Surg Oncol 36(1), 95-99.

23. Adams SC, Potter BK, Pitcher DJ, Temple HT (2010) Office-based core needle biopsy of bone and soft tissue malignancies: an accurate alternative to open biopsy with infrequent complications. Clin Orthop Relat Res 468(10), 2774-2780.

24. Khoja H, Griffin A, Dickson B, Wunder J, Ferguson P, Howarth D, Kandel R (2013) Sampling modality influences the predictive value of grading in adult soft tissue extremity sarcomas. Arch Pathol Lab Med 137(12), 1774-1779.

25. Wunder JS, Healey JH, Davis AM, Brennan MF (2000) A comparison of staging systems for localized extremity soft tissue sarcoma. Cancer 88(12), 2721-2730.

26. Dadia S, Grimer R (2007) Characteristics, diagnosis and treatment of bone and soft tissue sarcomas. Br J Hosp Med (Lond) 68(11), 589-593.

27. Ghert MA, Abudu A, Driver N, Davis AM, Griffin AM, Pearce D, White L, O'Sullivan B, Catton CN, Bell RS, Wunder JS (2005) The indications for and the prognostic significance of amputation as the primary surgical procedure for localized soft tissue sarcoma of the extremity. Ann Surg Oncol 12(1), 10-17.

28. O'Sullivan B, Davis AM, Turcotte R, Bell R, Catton C, Chabot P, Wunder J, Kandel R, Goddard K, Sadura A, Pater J, Zee B (2002) Preoperative versus postoperative radiotherapy in softtissue sarcoma of the limbs: a randomised trial. Lancet 359(9325), 2235-2241.

29. Griffin AM, Dickie CI, Catton CN, Chung PW, Ferguson PC, Wunder JS, O'Sullivan B (2015) The influence of time interval between preoperative radiation and surgical resection on the development of wound healing complications in extremity soft tissue sarcoma. Ann Surg Oncol 22(9), 2824-2830.

30. O'Sullivan B, Griffin AM, Dickie CI, Sharpe MB, Chung PW, Catton CN, Ferguson PC, Wunder JS, Deheshi BM, White LM, Kandel RA, Jaffray DA, Bell RS (2013) Phase 2 study of preoperative image-guided intensity-modulated radiation therapy to reduce wound and combined modality morbidities in lower extremity soft tissue sarcoma. Cancer 119(10), 1878-1884.

31. Davis AM, O'Sullivan B, Turcotte R, Bell R, Catton C, Chabot P, Wunder J, Hammond A, Benk V, Kandel R, Goddard K, Freeman C, Sadura A, Zee B, Day A, Tu D, Pater J, Canadian Sarcoma G, Trial NCICCTGR (2005) Late radiation morbidity following randomization to preoperative versus postoperative radiotherapy in extremity soft tissue sarcoma. Radiother Oncol 75(1), 48-53. 
32. Davis AM, O'Sullivan B, Bell RS, Turcotte R, Catton CN, Wunder JS, Chabot P, Hammond A, Benk V, Isler M, Freeman C, Goddard K, Bezjak A, Kandel RA, Sadura A, Day A, James K, Tu D, Pater J, Zee B (2002) Function and health status outcomes in a randomized trial comparing preoperative and postoperative radiotherapy in extremity soft tissue sarcoma. J Clin Oncol 20(22), 4472-4477.

33. Al Yami A, Griffin AM, Ferguson PC, Catton CN, Chung PW, Bell RS, Wunder JS, O'Sullivan B (2010) Positive surgical margins in soft tissue sarcoma treated with preoperative radiation: is a postoperative boost necessary? Int J Radiat Oncol Biol Phys 77(4), 1191-1197.

34. Pan E, Goldberg SI, Chen YL, Giraud C, Hornick JL, Nielsen GP, Hornicek FJ, Raut CP, DeLaney TF, Baldini EH (2014) Role of post-operative radiation boost for soft tissue sarcomas with positive margins following pre-operative radiation and surgery. J Surg Oncol 110(7), 817-822.

35. Moreau LC, Turcotte R, Ferguson P, Wunder J, Clarkson P, Masri B, Isler M, Dion N, Werier J, Ghert M, Deheshi B, Canadian Orthopaedic Oncology S (2012) Myxoid \round cell liposarcoma (MRCLS) revisited: an analysis of 418 primarily managed cases. Ann Surg Oncol 19(4), 1081-1088.

36. Pitson G, Robinson P, Wilke D, Kandel RA, White L, Griffin AM, Bell RS, Catton CN, Wunder JS, O'Sullivan B (2004) Radiation response: an additional unique signature of myxoid liposarcoma. Int J Radiat Oncol Biol Phys 60(2), 522-526.

37. Chung PW, Deheshi BM, Ferguson PC, Wunder JS, Griffin AM, Catton CN, Bell RS, White LM, Kandel RA, O'Sullivan B (2009) Radiosensitivity translates into excellent local control in extremity myxoid liposarcoma: a comparison with other soft tissue sarcomas. Cancer 115(14), 3254-3261.

38. Townley WA, Mah E, O'Neill AC, Wunder JS, Ferguson PC, Zhong T, Hofer SO (2013) Reconstruction of sarcoma defects following pre-operative radiation: free tissue transfer is safe and reliable. J Plast Reconstr Aesthet Surg 66(11), $1575-1579$.

39. Griffin AM, Euler CI, Sharpe MB, Ferguson PC, Wunder JS, Bell RS, Chung PW, Catton CN, O'Sullivan B (2007) Radiation planning comparison for superficial tissue avoidance in radiotherapy for soft tissue sarcoma of the lower extremity. Int J Radiat Oncol Biol Phys 67(3), 847-856.

40. Biau DJ, Ferguson PC, Chung P, Griffin AM, Catton CN, O'Sullivan B, Wunder JS (2012) Local recurrence of localized soft tissue sarcoma: a new look at old predictors. Cancer 118(23), 5867-5877.

41. Gerrand CH, Wunder JS, Kandel RA, O'Sullivan B, Catton CN, Bell RS, Griffin AM, Davis AM (2001) Classification of positive margins after resection of soft-tissue sarcoma of the limb predicts the risk of local recurrence. J Bone Joint Surg Br 83(8), 1149-1155.

42. Noria S, Davis A, Kandel R, Levesque J, O'Sullivan B, Wunder J, Bell R (1996) Residual disease following unplanned excision of soft-tissue sarcoma of an extremity. J Bone Joint Surg Am 78(5), 650-655.

43. Clarkson PW, Griffin AM, Catton CN, O'Sullivan B, Ferguson PC, Wunder JS, Bell RS (2005) Epineural dissection is a safe technique that facilitates limb salvage surgery. Clin Orthop Relat Res 438, 92-96.

44. O'Donnell PW, Griffin AM, Eward WC, Sternheim A, Catton CN, Chung PW, O’Sullivan B, Ferguson PC, Wunder JS (2014)
The effect of the setting of a positive surgical margin in soft tissue sarcoma. Cancer 120(18), 2866-2875.

45. Jones KB, Ferguson PC, Deheshi B, Riad S, Griffin A, Bell RS, Wunder JS (2010) Complete femoral nerve resection with soft tissue sarcoma: functional outcomes. Ann Surg Oncol 17(2), 401-406.

46. Ghert MA, Davis AM, Griffin AM, Alyami AH, White L, Kandel RA, Ferguson P, O'Sullivan B, Catton CN, Lindsay T, Rubin B, Bell RS, Wunder JS (2005) The surgical and functional outcome of limb-salvage surgery with vascular reconstruction for soft tissue sarcoma of the extremity. Ann Surg Oncol 12(12), 1102-1110.

47. Holt GE, Griffin AM, Pintilie M, Wunder JS, Catton C, O'Sullivan B, Bell RS (2005) Fractures following radiotherapy and limb-salvage surgery for lower extremity soft-tissue sarcomas. A comparison of high-dose and low-dose radiotherapy. J Bone Joint Surg Am 87(2), 315-319.

48. Dickie CI, Parent AL, Griffin AM, Fung S, Chung PW, Catton CN, Ferguson PC, Wunder JS, Bell RS, Sharpe MB, O'Sullivan B (2009) Bone fractures following external beam radiotherapy and limb-preservation surgery for lower extremity soft tissue sarcoma: relationship to irradiated bone length, volume, tumor location and dose. Int J Radiat Oncol Biol Phys 75(4), 1119-1124.

49. Sternheim A, Saidi K, Lochab J, O’Donnell PW, Eward WC, Griffin A, Wunder JS, Ferguson P (2013) Internal fixation of radiation-induced pathological fractures of the femur has a high rate of failure. Bone Joint J 95-B(8), 1144-1148.

50. Gortzak Y, Lockwood GA, Mahendra A, Wang Y, Chung PW, Catton CN, O'Sullivan B, Deheshi BM, Wunder JS, Ferguson PC (2010) Prediction of pathologic fracture risk of the femur after combined modality treatment of soft tissue sarcoma of the thigh. Cancer 116(6), 1553-1559.

51. Megerle K, Sauerbier M (2011) Reconstructive treatment of soft tissue sarcoma of the upper extremity. J Hand Surg Am 36(7), 1241-1247.

52. Levin LS (1993) The reconstructive ladder. An orthoplastic approach. Orthop Clin North Am 24(3), 393-409.

53. Senchenkov A, Petty PM, Knoetgen J 3rd, Moran SL, Johnson $\mathrm{CH}$, Clay RP (2007) Outcomes of skin graft reconstructions with the use of Vacuum Assisted Closure (VAC(R)) dressing for irradiated extremity sarcoma defects. World J Surg Oncol 5, 138.

54. Fleming ME, O’Daniel A, Bharmal H, Valerio I (2014) Application of the orthoplastic reconstructive ladder to preserve lower extremity amputation length. Ann Plast Surg 73(2), 183-189.

55. Enneking WF (1987) Modification of the system for functional evaluation in the surgical management of musculoskeletal tumors Limb Salvage in Musculoskeletal Oncology. New York, Churchill-Livingston.

56. Davis AM, Wright JG, Williams JI, Bombardier C, Griffin A, Bell RS (1996) Development of a measure of physical function for patients with bone and soft tissue sarcoma. Qual Life Res 5(5), 508-516.

57. Enneking WF, Dunham W, Gebhardt MC, Malawar M, Pritchard DJ (1993) A system for the functional evaluation of reconstructive procedures after surgical treatment of tumors of the musculoskeletal system. Clin Orthop Relat Res 286, 241-246. 
58. Davis AM, Sennik S, Griffin AM, Wunder JS, O'Sullivan B, Catton CN, Bell RS (2000) Predictors of functional outcomes following limb salvage surgery for lower-extremity soft tissue sarcoma. J Surg Oncol 73(4), 206-211.

59. Gerrand CH, Wunder JS, Kandel RA, O'Sullivan B, Catton CN, Bell RS, Griffin AM, Davis AM (2004) The influence of anatomic location on functional outcome in lower-extremity soft-tissue sarcoma. Ann Surg Oncol 11(5), 476-482.

60. Schreiber D, Bell RS, Wunder JS, O'Sullivan B, Turcotte R, Masri BA, Davis AM (2006) Evaluating function and health related quality of life in patients treated for extremity soft tissue sarcoma. Qual Life Res 15(9), 1439-1446.

61. Davidge K, Bell R, Ferguson P, Turcotte R, Wunder J, Davis AM (2009) Patient expectations for surgical outcome in extremity soft tissue sarcoma. J Surg Oncol 100(5), 375-381.

62. Riad S, Biau D, Holt GE, Werier J, Turcotte RE, Ferguson PC, Griffin AM, Dickie CI, Chung PW, Catton CN, O'Sullivan B, Wunder JS (2012) The clinical and functional outcome for patients with radiation-induced soft tissue sarcoma. Cancer 118(10), 2682-2692.
63. Payne CE, Hofer SO, Zhong T, Griffin AC, Ferguson PC, Wunder JS (2013) Functional outcome following upper limb soft tissue sarcoma resection with flap reconstruction. J Plast Reconstr Aesthet Surg 66(5), 601-607.

64. Wright EH, Gwilym S, Gibbons CL, Critchley P, Giele HP (2008) Functional and oncological outcomes after limb-salvage surgery for primary sarcomas of the upper limb. J Plast Reconstr Aesthet Surg 61(4), 382-387.

65. Davidge KM, Wunder J, Tomlinson G, Wong R, Lipa J, Davis AM (2010) Function and health status outcomes following soft tissue reconstruction for limb preservation in extremity soft tissue sarcoma. Ann Surg Oncol 17(4), 1052-1062.

66. Davis AM, Punniyamoorthy S, Griffin AM, Wunder JS, Bell RS (1999) Symptoms and their relationship to disability following treatment for lower extremity tumours. Sarcoma 3(2), 73-77.

67. Pradhan A, Cheung YC, Grimer RJ, Abudu A, Peake D, Ferguson PC, Griffin AM, Wunder JS, O'Sullivan B, Hugate R Jr, Sim FH (2006) Does the method of treatment affect the outcome in soft-tissue sarcomas of the adductor compartment? J Bone Joint Surg Br 88(11), 1480-1486.

Cite this article as: Ramu EM, Houdek MT, Isaac CE, Dickie CI, Ferguson PC \& Wunder JS (2017) Management of soft-tissue sarcomas; treatment strategies, staging, and outcomes. SICOT J, 3, 20 